\title{
GMR
}

\section{Genetic diversity of Casearia sylvestris populations in remnants of the Atlantic Forest}

F.L. Araujo ${ }^{1}$, M.V.B.M. Siqueira ${ }^{2}$, C. Grando ${ }^{3}$, J.P.G. Viana ${ }^{3}$, J.B. Pinheiro ${ }^{4}$, A. Alves-Pereira ${ }^{4}$, J.B. Campos ${ }^{3}$, P.H.S. Brancalion ${ }^{5}$ and M.I. Zucchi ${ }^{6}$

${ }^{1}$ Centro de Recursos Genéticos Vegetais, Instituto Agronômico, Campinas, SP, Brasil

${ }^{2}$ Universidade do Sagrado Coração, Bauru, SP, Brasil

${ }^{3}$ Programa de Pós-Graduação em Genética e Biologia Molecular, Universidade de Campinas, Campinas, SP, Brasil

${ }^{4}$ Departamento de Genética, Escola Superior de Agricultura Luiz de Queiroz, Universidade de São Paulo, Piracicaba, SP, Brasil

${ }^{5}$ Departamento de Ciências Florestais, Escola Superior de Agricultura Luiz de Queiroz, Universidade de São Paulo, Piracicaba, SP, Brasil

${ }^{6}$ Agência Paulista de Tecnologia dos Agronegócios, Pólo Regional Centro Sul, Piracicaba, SP, Brasil

Corresponding author: F.L. Araujo

E-mail: fabiano.biolucas@hotmail.com

Genet. Mol. Res. 16 (1): gmr16019105

Received August 30, 2016

Accepted November 8, 2016

Published January 23, 2017

DOI http://dx.doi.org/10.4238/gmr16019105

Copyright $(92017$ The Authors. This is an open-access article distributed under the terms of the Creative Commons Attribution ShareAlike (CC BY-SA) 4.0 License.

ABSTRACT. Guaçatonga (Casearia sylvestris) is a native plant of the Atlantic Forest, with high medicinal potential and relevance for reforestation programs. The aim of this study was to characterize, with microsatellite markers, two populations of $C$. sylvestris from remaining areas of the Atlantic Forest in the State of São Paulo. High allelic variation was found in both populations $\left(N_{\mathrm{A}}=101\right.$ and $117 ; A_{\mathrm{R}}$ $=12.5$ and 14.4), although with high endogamy coefficients $(f=0.640$ 
and 0.363$)$. Estimates of genetic structure suggested the presence of considerable genetic divergence between the populations $\left(F_{\mathrm{ST}}=0.103\right)$; however, there was no spatial genetic structure within the populations. Genetic divergence may have occurred due to decreased gene flow between the fragmented populations as the result of deforestation. The results of this study demonstrate the importance of genetic diversity and its characterization in native plants within remaining forest areas for the management and restoration of such areas.

Key words: Guaçatonga; Molecular markers; Restoration; Spatial genetic structure

\section{INTRODUCTION}

Brazil possesses the highest diversity of plant species in the world, including some with high medicinal potential, both in the Atlantic Forest and in other biomes (Souza-Moreira et al., 2010). Originally, the Atlantic Forest covered almost the entire Brazilian coast, extending into Paraguay and Argentina. Colonization and urbanization processes, as well as industrialization and the irregular occupation of forest land, have decreased its size to preserved areas, which are today limited to fragments of the original forest (Morellato and Haddad, 2000).

In the State of São Paulo, destruction of the forest has already reached approximately $79,500 \mathrm{~km}^{2}$ (Rodrigues et al., 2009). Furthermore, the exploration of native forests and extractivism without management strategies have resulted in greater fragmentation and biodiversity decline, reducing the viability of plant species (Rodrigues et al., 2011).

Currently, the Atlantic Forest is deemed one of the world's most important biomes, and is considered a hotspot for the conservation movement due to its high degree of endemism and the number of threatened species (Myers et al., 2000; Martini et al., 2007). Nevertheless, less than $10 \%$ of the vegetal species of the Atlantic Forest have been evaluated for their biological characteristics, and less than 5\% have been subjected to detailed phytochemical and genetic analyses (Luna et al., 2005). Habitat loss and isolation of forest fragments can be observed by the decreased genetic variability, which decreases the population's effective size, and through a possible increase in endogamy, which may contribute to the decreasing reproductive success of the plant population (Hartl and Clark, 2010).

Many remaining native forest species have medicinal potential, and are important, especially for the rural population, (Oliveira et al., 2011), for pharmacological research (Ferreira et al., 2011) and forest reforestation. Among these species, guaçatonga (Casearia sylvestris, Salicaceae), which has known pharmacological potential (Backes and Irgang, 2002), has a crucial role in these fragile ecosystems. Although studies on its phytotherapical characteristics have been performed, few have investigated the biological, genetic, and reproductive characteristics of this species.

In order to maintain biological diversity and assure existing ecological processes, measures aimed at the conservation and recovery of the remaining forest biomes are required, taking into consideration the maintenance of genetic diversity, as well as the use of native species in plantations (Rodrigues et al., 2009). Therefore, genetic studies on C. sylvestris are necessary to provide an understanding of the structure and genetic diversity of its populations, which could be used to subsidize reforesting programs. Thus, this study's aim was to

Genetics and Molecular Research 16 (1): gmr16019105 
characterize, with microsatellite markers, two populations of $C$. sylvestris from the remaining forests of the Atlantic forest of the State of São Paulo.

\section{MATERIAL AND METHODS}

\section{Study sites}

The study was carried out in two areas of Atlantic Forest remnants of the State of São Paulo. The first area was Mata Santa Genebra (Santa Genebra Woods) (2249'20"S, $47^{\circ} 06^{\prime} 40^{\prime \prime} \mathrm{W}$ ), in the city of Campinas, covering approximately 252 hectares. The area is inserted in a matrix constituted by an annual and perennial mosaic of cultures, pastures, reforestation, and few human settlements (Guirão and Filho, 2011). The second area was Estação Experimental do Tietê (Tietê Experimental Station) $\left(22^{\circ} 00^{\prime} 20^{\prime \prime} \mathrm{S}, 4^{\circ} 43^{\prime} 38^{\prime \prime} \mathrm{W}\right)$, located in the municipality of Tietê, occupying an area of 253.8 hectares. In each area, young leaves of 46 individual C. sylvestris samples were harvested. The samples were conditioned in liquid nitrogen and each individual sample was georeferenced.

\section{DNA extraction and inter-simple sequence repeat (ISSR) amplification}

The Doyle and Doyle (1990) protocol was used to extract DNA from samples. The quality and amount of extracted DNA were determined by electrophoresis on a $1 \%(\mathrm{p} / \mathrm{v})$ agarose gel colored with SYBR safe DNA gel stain (Invitrogen), by comparison with a molecular weight Lambda marker (Invitrogen). Genetic characterization was performed based on eight microsatellite markers as described by Cavallari et al. (2008) (Table 1). The microsatellites were amplified by PCR and allele size was determined using the semiautomatic sequencer LI-COR DNA Analyzer 4300 (LI-COR Corporate), as described by Cavallari et al. (2010).

Table 1. Genetic diversity estimates for eight loci microsatellites in two populations of Casearia sylvestris.

\begin{tabular}{l|c|c|c|c|c}
\hline Locus & Variation (bp) & $N_{\mathrm{A}}$ & $H_{\mathrm{O}}$ & $H_{\mathrm{E}}$ & $f$ \\
\hline Csy04 & $138-168$ & 15 & 0.489 & 0.890 & 0.452 \\
\hline Csy06 & $258-298$ & 20 & 0.663 & 0.923 & 0.282 \\
\hline Csy07 & $228-264$ & 19 & 0.253 & 0.917 & 0.730 \\
\hline Csy11 & $128-176$ & 21 & 0.283 & 0.929 & 0.693 \\
\hline Csy14 & $259-298$ & 24 & 0.066 & 0.948 & 0.929 \\
\hline Csy15 & $209-300$ & 29 & 0.382 & 0.928 & 0.599 \\
\hline Csy16 & $220-289$ & 19 & 0.554 & 0.935 & 0.404 \\
\hline Csy18 & $261-311$ & 21 & 0.815 & 0.925 & 0.528 \\
\hline
\end{tabular}

Variation in allele size is shown in base pairs (bp), $N_{\mathrm{A}}=$ total number of alleles, $H_{\mathrm{O}}=$ observed heterozygosity, $H_{\mathrm{E}}$ $=$ expected heterozygosity, $f=$ inbreeding coefficient.

\section{Data analysis}

Parameters of genetic diversity were estimated as follows: numbers of alleles per locus $\left(N_{\mathrm{A}}\right)$; medium number of alleles per locus $(\bar{A})$; allelic fullness $\left(A_{\mathrm{R}}\right)$; observed heterozygosity $\left(H_{\mathrm{O}}\right)$ and expected heterozygosity $\left(H_{\mathrm{E}}\right)$, in addition to the coefficient of intrapopulation endogamy $(f)$, using the FSTAT program (Goudet, 1995). The relevance of $f$ was determined based on 20,000 permutations, based on the value of $\alpha=0.05$ adjusted by the Bonferroni 
correction (Rice, 1989). Nei (1972)'s genetic distance among individuals was used to construct the dendrogram with the neighbor-joining method in the program Populations (Langella, 1999). Group reliability was evaluated by bootstrap (1000 replications).

The genetic structures among populations were quantified by estimating F-Statistics (Weir and Cockerhan, 1984), calculated with the GDA program (Lewis and Zaykin, 2001). The genetic spatial structure among the populations was evaluated based on the coefficient of kinship estimated from J. Nason (Loiselle et al., 1995), and calculated with the SPAGeDI program (Hardy and Vekemans, 2002). Correlograms were plotted among the coefficient of medium kinship and classes of defined distance for each population, and a confidence interval of $95 \%$ was calculated for each class of distance, based on 1000 Jackknife replicas. However, the majority of loci presented low-to-medium estimates of heterozygosity.

\section{RESULTS AND DISCUSSION}

The microsatellite markers used in this study exhibited high allelic variation, with $N_{\mathrm{A}}$ varying from 15 (Csy04) to 29 (Csy15) (Table 1). However, most of the loci reported estimates of heterozygosity ranging from low to medium, such that all loci presented a high heterozygote deficit, with high endogamy coefficient values, and $f$ varying from 0.129 to 0.929 (Table 1). Estimates of allelic diversity were slightly higher in the populations from Tietê, in comparison to the populations of Santa Genebra (Table 2). From the 117 alleles found in Tietê populations, 67 were not identified in Santa Genebra populations. Conversely, from the 101 alleles found in Santa Genebra populations, 51 were not identified in the Tietê populations. The populations of Tietê presented higher $H_{\mathrm{O}}$ and lower $f$ than Santa Genebra populations $\left(H_{\mathrm{O}}\right.$ $=0.562$ and $0.313 ; f=0.363$ and 0.640 , respectively) (Table 2). Estimates of genetic diversity obtained in the present study supported the results obtained by Cavallari et al. (2010). Those authors evaluated nine populations of two varieties of C. sylvestris (sylvestris and lingua) and found high indexes of allelic diversity, with an average number higher than 15 alleles per locus in the sylvestris variety.

Table 2. Genetic diversity estimates for both populations of Casearia sylvestris based on eight microsatellite loci.

\begin{tabular}{l|c|c|c|c|c|c|c|c}
\hline Population & $\mathrm{N}$ & $N_{\mathrm{A}}$ & $\bar{A}$ & $A_{R}$ & $\mathrm{Ap}$ & $H_{\mathrm{O}}$ & $H_{\mathrm{E}}$ & $f$ \\
\hline Santa Genebra & 46 & 101 & 12.6 & 12.5 & 51 & 0.313 & 0.864 & $0.640^{*}$ \\
\hline Tietê & 46 & 117 & 14.6 & 14.4 & 67 & 0.562 & 0.880 & $0.363^{*}$ \\
\hline
\end{tabular}

$\mathrm{N}=$ number of sampled individuals, $N_{\mathrm{A}}=$ total number of alleles, $\bar{A}=$ average number of alleles per locus, $A_{\mathrm{R}}=$ allelic richness, $\mathrm{Ap}=$ number of private alleles, $H_{\mathrm{O}}=$ observed heterozygosity, $H_{\mathrm{E}}=$ expected heterozygosity, $f=$ inbreeding coefficient. *Significant at $\mathrm{P} \leq 0.05$.

Estimated values for the F-statistics were elevated compared with those reported by Weir and Cockerham (1984), with $F_{\mathrm{IT}}=0.552, F_{\mathrm{ST}}=0.103$, and $F_{\mathrm{IS}}=0.500$, which were significantly different from zero. The $F_{\mathrm{ST}}$ value suggests there is a high level of genetic divergence among $C$. sylvestris populations in the remaining forests of Santa Genebra and Tietê, which is consistent with the high number of private alleles found. Apart from this divergence, the values of the F-statistics suggested that most of the total inbreeding observed $\left(F_{\mathrm{IT}}\right)$ was due to the panmixia deviation and the occurrence of inbreeding within the Santa Genebra and Tiete populations $\left(F_{\text {IS }}=0.500\right)$. The elevated $F_{\text {IS }}$ value reflects the increased heterozygote deficiency in these populations, as suggested by the elevated values of $f$ shown

Genetics and Molecular Research 16 (1): gmr16019105 
in Table 2. This may also be related to the reproductive system of $C$. sylvestris. The elevated inbreeding coefficient values and $F_{\text {IS }}$ may indicate that self-fertilization is common in the populations of Santa Genebra and Tietê. The results of the individual grouping analysis, based on neighbor-joining algorithm and Nei (1972)'s distance, are consistent with the elevated genetic divergence found among the populations of $C$. sylvestris (Figure 1). Two large groups were formed, which separated the individuals of these populations.

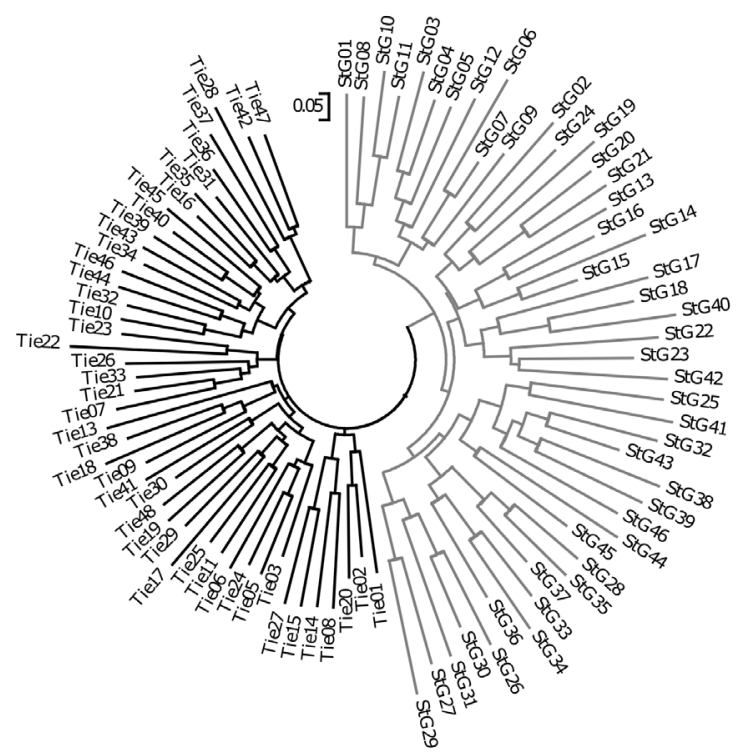

Figure 1. Dendrogram generated using the Neighbor-joining method, based on Nei's distance (1972), showing the groupings of Casearia sylvestris individuals from the populations of Santa Genebra (clearer branches) and Tietê (darker branches).

The high genetic divergence observed between the populations of Santa Genebra and Tietê is most likely related to the low gene flow resulting from forest fragmentation (Frankham et al., 2008). Similar results were found for the Copaíba tree (Copaifera langsdorffii) by Martins et al. (2008), whereby it was suggested that forest fragmentation restricts gene flow between populations of these species, possibly due difficulty in pollinator movement. The genetic isolation may also be related to the high number of private alleles found in this study (Karasawa, 2005).

In general, the kinship coefficients of J. Nason (Loiselle et al., 1995) were low, and no spatial autocorrelation was found in the two populations, such that $C$. sylvestris individuals presented variable kinship coefficients between the classes of distance (Figure 2). The absence of a correlation between kinship and distance between individuals can be indicative of endogamy in the populations of $C$. sylvestris over the entire area of Santa Genebra and Tietê.

Despite the elevated estimates of allelic diversity, the results obtained in this study suggest there was an increased rate of inbreeding among the $C$. sylvestris populations in the remaining forests of Santa Genebra and Tietê. Additionally, considerable divergence could be observed, which was most likely related to gene flow among the isolated fragmented areas of the Atlantic Forest. The fragmentation of the populations, and the absence of interconnected ecological corridors, has resulted in a high level of genetic divergence, preventing genetic

Genetics and Molecular Research 16 (1): gmr16019105 

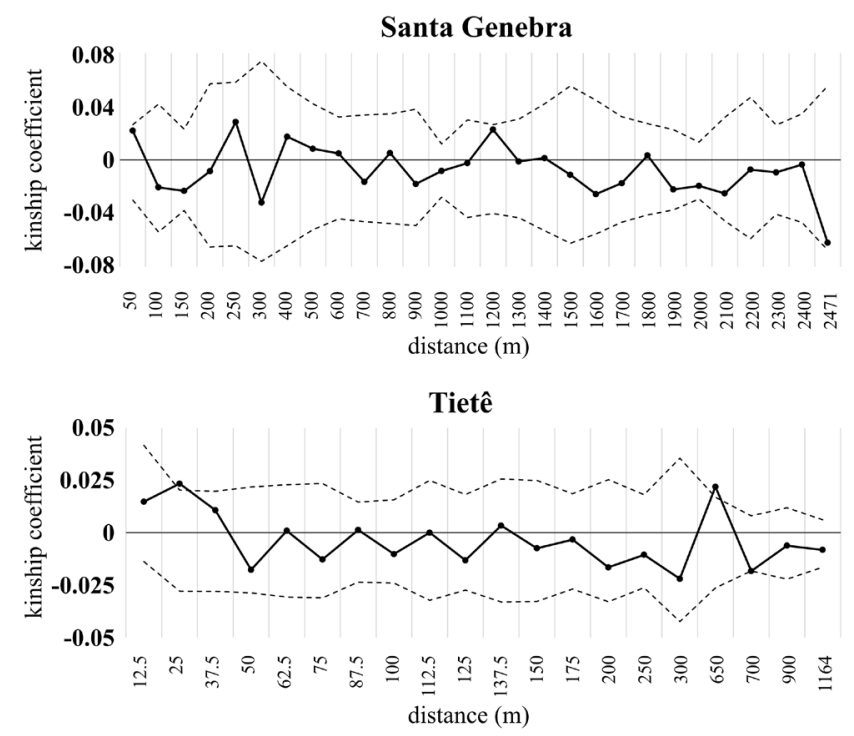

Figure 2. Correlogram exhibiting kinship coefficient measures in populations from Santa Genebra and Tietê for each class of distance (indicated by maximum distance in meters). The dashed lines indicate critic values (upper and lower) with $95 \%$ confidence interval.

exchange, and increasing the effects of inbreeding and genetic drifts (Rodrigues et al., 2011). Genetic studies carried out in populations of native plants in remaining forest areas can provide essential information for the management and recovery of these areas. In this context, from a genetic perspective, the results of this study support the use of microsatellite markers for the characterization of genetic diversity in C. sylvestris populations in remaining forests. In addition, this study supports the relevance of strategies that aim to recover degraded forest areas and create ecological corridors, permitting connectivity between remaining forests that are currently isolated.

\section{Conflicts of interest}

The authors declare no conflict of interest.

\section{ACKNOWLEDGMENTS}

Research supported by Coordenação de Aperfeiçoamento de Pessoal de Nível Superior (CAPES) and Fundação de Amparo à Pesquisa do Estado de São Paulo (FAPESP). We are also grateful to Dr. Leila Maria Felipini for the English revision.

\section{REFERENCES}

Backes P and Irgang B (2002). Árvores do sul: guia de identificação e interesse ecológico. Impressora Pallotti, Vila Flores. Cavallari MM, Billot C, Bouvet JM, Favreau B, et al. (2008). Isolation and characterization of microsatellite markers for Casearia sylvestris Sw. (Salicaceae), a neotropical medicinal tree. Mol. Ecol. Resour. 8: 802-804. http://dx.doi. org/10.1111/j.1755-0998.2007.02069.x

Genetics and Molecular Research 16 (1): gmr16019105 
Cavallari MM, Gimenes MA, Billot C, Torres RB, et al. (2010). Population genetic relationships between Casearia sylvestris (Salicaceae) varieties occurring sympatrically and allopatrically in different ecosystems in south-east Brazil. Ann. Bot. (Lond.) 106: 627-636. http://dx.doi.org/10.1093/aob/mcq151

Doyle JJ and Doyle JL (1990). A rapid total DNA preparation procedure for fresh plant tissue. Focus 12: 13-15.

Ferreira PMP, Costa-Lotufo LV, Moraes MO, Barros FWA, et al. (2011). Folk uses and pharmacological properties of Casearia sylvestris: a medicinal review. An. Acad. Bras. Cienc. 83: 1373-1384. http://dx.doi.org/10.1590/S000137652011005000040

Frankham R, Ballou JD and Briscoe DA (2008). Fundamentos de Genética da Conservação. SBG, Sociedade Brasileira de Genética, Ribeirão Preto.

Goudet J (1995). FSTAT version 1.2: a computer program to calculate F-statistics. J. Hered. 86: 485-486.

Guirão AC and Filho JT (2011). Preservação de um fragmento florestal urbano - Estudo de caso: A ARIE Mata de Santa Genebra, Campinas-SP. GEOUSP: Espaço e Tempo 29: 147-158. http://dx.doi.org/10.11606/issn.2179-0892. geousp.2011.74193

Hardy OJ and Vekemans X (2002). SPAGeDi: a versatile computer progrm to analyse spatial genetic structure at the individual or population levels. Mol. Ecol. Notes 2: 618-620. http://dx.doi.org/10.1046/j.1471-8286.2002.00305.x

Hartl DL and Clark AG (2010). Princípios de Genética de Populações. 4th edn. Editora Artmed, Porto Alegre.

Karasawa MMG (2005). Análise da estrutura genética de populações e sistema reprodutivo de Oryza glumaepatula por meio de microssatélites. Doctoral thesis. Universidade de São Paulo, Escola Superior de Agricultura "Luiz de Queiroz", Piracicaba.

Langella O (1999). Populations, Populations Genetic Software. Versão 1.2.28. Avaliado em [http://bioinformatics. org/ tryphon/populations/index.html\#pubdas]. Accessed 12 June 2014

Lewis PO and Zaykin D (2001). Genetics Data Analysis: computer program for the analysis of allelic data. Version 1.0. Available at [http://www.alleyn.eeb.uconn.edu/gda/]. Accessed June 12, 2014

Loiselle BA, Sork VL, Nason J and Graham C (1995). Spatial genetic structure of a tropical understory shrub, Psychotria officinalis (Rubiaceae). Am. J. Bot. 82: 1420-1425. http://dx.doi.org/10.2307/2445869

Luna J de S, dos Santos AF, de Lima MR, de Omena MC, et al. (2005). A study of the larvicidal and molluscicidal activities of some medicinal plants from northeast Brazil. J. Ethnopharmacol. 97: 199-206. http://dx.doi.org/10.1016/j. jep.2004.10.004

Martini AMZ, Fiaschi P, Amorim AM and Paixao JL (2007). A Hot-point within hot-spot: a high diversity site in Brazil Atlantic Forests. Biodivers. Conserv. 16: 3111-3128. http://dx.doi.org/10.1007/s10531-007-9166-6

Martins K, Dos Santos JD, Gaiotto FA, Moreno MA, et al. (2008). Estrutura genética populacional de Copaifera langsdorffi Desf. (Leguminosae - Caesalpinioideae) em fragmentos florestais no Pontal do Paranapanema, SP, Brasil. Rev. Bras. Bot. Braz. J. Bot. 31: 61-69. http://dx.doi.org/10.1590/S0100-84042008000100007

Morellato LPC and Haddad CFB (2000). Introduction: The Brazilian Atlantic Forest. Biotropica 32: 786-792. http:// dx.doi.org/10.1111/j.1744-7429.2000.tb00618.x

Myers N, Mittermeier RA, Mittermeier CG, da Fonseca GA, et al. (2000). Biodiversity hotspots for conservation priorities. Nature 403: 853-858. http://dx.doi.org/10.1038/35002501

Nei M (1972). Genetic distance between populations. Am. Nat. 106: 283-292. http://dx.doi.org/10.1086/282771

Oliveira LS, Muzitano MF, Coutinho MAS, Melo GO, et al. (2011). Plantas medicinais com recursos terapêutico em comunidades do entorno da reserva biológica do Tingá, RJ, Brasil - Metabólitos secundários e aspectos farmacológicos. Rev. Cient. Int. 17: 54-74.

Rice WR (1989). Analyzing tables of statistical tests. Evolution 43: 223-225. http://dx.doi.org/10.2307/2409177

Rodrigues RR, Brancalion PHS and Isernhagen I (2009). Pacto pela restauração da mata atlântica: referencial dos conceitos e ações de restauração florestal. Instituto Bio Atlântico, LERF/ESALQ, São Paulo.

Rodrigues RR, Gandolfi S, Nave AG, Aronson J, et al. (2011). Large-scale ecological restoration of high-diversity tropical forests in SE Brazil. For. Ecol. Manage. 261: 1605-1613. http://dx.doi.org/10.1016/j.foreco.2010.07.005

Souza-Moreira TM, Salgado HRN and Pietro RCLR (2010). O Brasil no contexto de controle de qualidade de plantas medicinai. Rev. Bras. Farmacogn 20: 435-440. http://dx.doi.org/10.1590/S0102-695X2010000300023

Weir BS and Cockerham CC (1984). Estimating F-estatistics for the analysis of population structure. Evolution 38: 1358 1370. http://dx.doi.org/10.2307/2408641

Genetics and Molecular Research 16 (1): gmr16019105 